\title{
JURNALISME PUBLIK \& JURNALISME WARGA SERTA PERANNYA DALAM MENINGKATKAN PARTISIPASI WARGA DALAM PROSES DEMOKRASI
}

\author{
Dodot Sapto Adi \\ dodotrebelian@gmail.com \\ Program Studi Ilmu Komunikasi FISIP Universitas Merdeka Malang
}

\begin{abstract}
Abstrak
Sebagai lembaga sosial dan penyanggah demokrasi keempat, media berfungsi untuk mengontrol perilaku kekuasaan politik penguasa dan kuasa ekonomi pengusaha. Namun sebagai lembaga ekonomi, media juga dikelola untuk melayani kepentingan ekonomi politiknya sendiri. Media tidak dikelola dalam ruang hampa; media dijalankan dengan dorongan dan motivasi untuk melayani kepentingan ekonomi dan politiknya sendiri agar tetap bertahan hidup. Isi media dan realitas media, makanya bukan merupakan pantulan jujur dari realitas sosial tapi adalah konstruksi dan bentukan dari para pekerja media. Konten pemberitaan media, makanya, seakan terpisah jauh dari kepentingan masyarakat. Kepentingan publik belum menjadi arus utama dalam rutinitas kerja redaksi. Kinerja pers seperti ini telah menimbulkan sinisme masyarakat terhadap kehidupan publik. Jurnalisme publik/civic, makanya menjadi keniscayaan sejarah bagi pekerja pers untuk mengembalikan fungsi pers sebagai pilar demokrasi keempat. Lewat model jurnalisme ini diharapkan sikap apatis masyarakat dapat diganti dengan partisipasi penuh mereka dalam kehidupan warga. Ditambah dengan jurnalisme warga, partisipasi warga dalam mempengaruhi kebijikan publik akan semakin marak. Artikel konseptual ini berupaya untuk menjelaskan esensi jurnalisme publik beserta latar belakang yang mendorong kelahirannya. Model jurnalisme ini semakin bertampah daya dorongnya dengan munculnya jurnalisme warga. Tulisan ini menyimpulkan bahwa kedua model jurnalisme penting untuk memelihara proses demokratisasi nasional.
\end{abstract}

Kata Kunci : Jurnalisme Publik, Jurnalisme Civic, Jurnalisme warga, pillar keempat demokrasi

\begin{abstract}
National press ideally should become a fourth pillar of democracy by means of controlling state actors and private sector effectively. This ideal practically never materializes since press it is an economic entity operating to serve its economic and political interests. As such, it never works in vacuum. It conducts its journalistic work to meet its vested-interest in order to survive. This was done unfortunately at the expenses of sacrificing its duties to serve public interest as its top priority. It is not surprising to see that issues covered are detached from the interest of the public. What being reported and disseminated in the press are consistent with the people's advantage. This calls for public or civic journalism to reconnect the society with both government and news media. By doing so, press would able to accelerate people' participation and involve them at decision proses making which affect their life. Citizen journalism which come into being as the result of information and communication technology advancement have people's involvement at public life even stronger. This article tries to explicate the essence of public or civic journalism along with its brief historical account. Combined with citizen journalism, public journalism could pave the way for people's political participation within public life.
\end{abstract}

Key Word; Public Journalism, Civic Journalism, Citizen Journalism, Press, Fourth Pillar of Democracy 


\section{Pendahuluan}

Wartawan sering terjebak dalam pada bad news is good news syndrome. Berita cenderung bersifat dari atas ke bawah (topdown) dengan mengutip berbagai berbagai pernyataan pejabat pemerintah atau swasta. Jadi, agenda setting media lebih bersifat elitis alias dibuat oleh segelintir orang kuat. Tidak ada ruang yang cukup bagi warga masyarakat untuk menjadi nara sumber dan mengemukakan agenda mereka sendiri. Mereka tidak diberi kesempatan untuk menyampaikan solusi mereka sendiri, tetapi mereka selalu 'disuapi' dan dicekoki' jalan keluar oleh pihak lain yang mungkin saja belum sesuai dengan kondisi mereka. Wartawan seperti terpisah dari realitas warga masyarakat yang dikonstruksi dalam media. Tidak heran, kalau agenda media selalu berbeda dengan agenda publik. Apa yang diinginkan warga masyarakat tidak mampu diakomodir oleh pengelola media. Sebaliknya, media lebih senang 'bermain-main' dengan agenda dan kepentingan sempit mereka sendiri. Ini diperkuat dengan temuan penelitian oleh Lembaga Konsumen Media (Media Watch Surabaya) tahun 2001 dan Ronny H Mustamu tahun 2002. Ronny menemukan bahwa dari empat media cetak lokal yang dikaji ; Surya, Kompas, Jawapos, dan Surabaya Post ternyata tidak ada satu mediapun yang agenda media mereka sama dengan agenda publik.

Disamping itu, para jurnalis telah kehilangan sense of humanazing yang memandu mereka saat melaksanakan kegiatan jurnalistik. Perasaan ini sebagai penjabaran dari layanan publik (public service) seharusnya mampu mendorong mereka untuk menempatkan kepentingan publik sebagai prioritas utama kegiatan jurnalistik mereka. Hal ini bisa diwujudkan dengan sajian media yang mampu merangsang masyarakat untuk peduli, lantas terlibat aktif dalam menyelesaikan masalah publik mereka sendiri. Media berkewajiban membuat masyarakat lebih proaktif dan media berfungsi sebagai katalisator. Setting inilah yang mendorong lahirnya konsep jurnalisme publik. Keadaan seperti ini pula yang mendesak segera dilaksanakannya konsep jurnalisme publik. Singkat kata, berita yang dibuat wartawan menjadi sangat elitis dengan menggunakan nara sumber elit pula dan sebagai akibatnya menggunakan perspektif elit yang sangat berbeda jauh dengan aspirasi dan kepentingan publik yang menjadi khalayak media. Nah, nilai penting jurnalisme publik ini kian mendapatkan momentum dengan hadirnya jurnalism warga akibat perkembangan teknologi komunikasi dan informasi. Menurut Minha Kim (2012 : 57) nilai penting jurnalisme publik semakin berlipat ganda dengan pemanfaatan teknologi komunikasi informasi yang kian interaktif.

Memasuki abad ke-21, pertumbuhan teknologi informasi dan komunikasi berkembang pesat. Internet menjadi lokomotif dari transformasi peradaban masa kini. Jurnalistik pun mendapatkan tantangan terbesarnya terutama sejak tahun 2000 dan memuncak pada dua tahun terakhir seiring pesatnya kemajuan dunia cyber. Tantangan itu berwujud sebuah konsep dan praktik yang disebut citizen journalism. Situasi berubah dan menuntut adaptasi bagi apa dan siapa saja yang ingin tetap bertahan hidup. Transformasi yang terjadi di ranah jurnalistik juga terjadi dalam rangka mempertahankan daya hidupnya. Transformasi tersebut tidak hanya terkait seputar perubahan dan penyesuaian perangkat atau instrumen pendukung yang digunakan. Akan tetapi, juga menyangkut aspek-aspek lain yang lebih luas, seperti praktik jurnalistik, sistem nilai dalam jurnalistik, pola dan sistem bisnis jurnalistik, hingga konsep-konsep dasar jurnalistik. Perubahan itu juga yang dibawa oleh gelombang citizen journalism.

Kini setiap pengguna internet dapat membuat media mereka sendiri secara gratis. Kehadiran komunitas blog merupakan revolusi komunikasi. Kegiatan pemberitaan telah beralih dari wartawan profesional kepada orang biasa sehingga memungkinkan berlangsungnya pertukaran pandangan yang lebih spontan, lebih 
interaktif serta lebih luas dari media konvensional. Dalam citizen journalism, masyarakat menjadi obyek sekaligus subjek berita. Mereka dapat menjadi penulis dan sekaligus mempublikasikannya. Inilah yang menempatkan setiap manusia menjadi subyek aktif dalam kehidupan sosial. Inilah era yang memungkinkan potensi setiap orang yang berasal dari golongan biasa-biasa saja bisa memiliki andil luar biasa bagi orang lain. Meskipun, satu sama lain tidak saling mengenal secara fisik. Tidak heran jika majalah TIME edisi 25 Desember 2006 lalu menutup edisi tahun tersebut dengan emilih "Person of The Year 2006" adalah Anda. Ya, Anda. Siapapun orang di muka bumi yang pernah berinteraksi dalam dunia maya. TIME mencatat bahwa tahun 2006 adalah tahun penanda peradaban masyarakat informasi. Tidak hanya di AS, tetapi di belahan bumi manapun dari Inggris di Eropa, Korea Selatan di Asia, hingga Maroko di Afrika. Situsweb berbasis citizen journalism bertajuk OhMyNews (ohmynews.com atau english. ohmynews.com) dari Korea Selatan menjadi contoh kekuatan baru di era informasi saat ini.

Nah, untuk Indonesia, komunitas blog masih sangat terbatas hanya pada kalangan tertentu saja. Seperti halamansatu.net baru mempunyai 59 penyumbang berita. Situs Wikimu.com baru didukung oleh 100an penyumbang berita. Hal ini berbeda dengan Ohmy.news milik Oh Yeon-ho, warga Korea Selatan yang memiliki 42 ribu kontributor berita dengan 200 artikel setiap harinya. Ohmy. News yang berslogan "Every Citizen is Reporter" dikunjungi 700 ribu orang setiap hari. Meski demikian, hal ini mengundang permasalahan besar terkait dengan etika penulisan dan kode etik jurnalistik. Sebab semua orang tanpa pengetahuan dan ketrampilan dalam bidang jurnalistik dalam menyajikan karya jurnalistik mereka serta mempublikasikannya sendiri. Pertanyaannya kemudian adalah sejauh mana aktivitas dan interaksi kita dalam jaringan citizen journalism tersebut-atau paling tidak sekadar sebagai pengguna pasif-memiliki manfaat sosial bagi lingkungan hidup kita sehari-hari, baik secara sosial, ekonomi, politik, maupun budaya. Ternyata, berita dalam dunia yang sarat informasi seperti sekarang ini dapat tampil dalam banyak sisi, tidak hanya satu muka karena siapa saja dapat mengartikan dan menginterpretasikan peristiwa dalam ruang dialog bersama yang berprinsip citizen journalism.

Fenomena ini telah diadopsi oleh Metro TV lewat tayangan vidio amatir yang ditayangkan oleh stasiun tersebut setiap hari Jum'at malam sekitar pukul 19:00. Tidak hanya menayangkan, Metro juga melakukan wawancara lewat telpon dengan sang pencipta tayangan berita tersebut. Namun mulai akhir April tahun 2008, acara tersebut disajikan dalam program khusus bertajuk "I witness" yang ditayangkan setiap Jum'at malam. Kemudian beraubah menjadi Wideshot. Net TV kemudian juga mengikuti langkah ini lewat program citizen journalist yang memberikan kepada hasil liputan mereka untuk ditayangkan dalam program NetCj. Geliat jurnalisme warga dilakukan oleh media cetak lokal Jawa Timur, yakni Harian Surya yang memberikan ruang satu halaman untuk masyarakat agar mengisinya dengan liputan berita artikel. Bahkan pihak redaksi Surya tidak pernah menyunting tulisan yang dikirim. Yang menarik adalah bahwa foto penulis beserta gambar peristiwa yang diliput juga ikut ditayangkan di media tersebut beserta nama lengkap dan alamat domisili dan email address. Satu rubrik bertajuk Warteg ini terbit setiap hari kecuali hari Minggu. Nah untuk media radio, Suara Surabaya FM telah lama melakukan karena radio semenjak awal telah mendeklarasikan dirinya sebagai radio berita semenjak didirikan pada awal tahun 19800an. Pada acara siaran Kelana Kota yang memuat berita tentang kesibukan berlalu lintas di kota Metropolitan Surabaya dan layanan publik, pendengar dapat langsung menyampaikan berita sekitar lalu lintas dan beberapa layanan 
publik yang dianggap tidak sesuai dengan kepentingan rakyat.

Dengan demikian dapat dikatakan bahwa para warga masyarakat amatir yang terlibat dalam proses pemberitaan baik di Metro TV, radio Suara Surabaya FM dan Harian Surya merupakan sekolompok warga yang peduli kepada lingkungan sekitar, bertanggungjawab terhadap diri sendiri dan orang lain serta ingin melihat bahwa semua penyelenggaraan layanan publik terlaksana demi kepentingan masyarakat bersama. Mereka menganggap keberadaan ruang berekspresi di media tersebut sebagai sarana untuk memperluas kepedulian serta mengajak warga lain untuk ikut berpartisipasi dalam menyelenggarakan kehidupan bersama. Mereka yakin bahwa bahwa penyelenggaraan kehidupan berbangsa dan bernegara ini tidak akan dapat lancar tanpa keikutsertaan mereka dalam menuntut dan mendesak akuntabilitas para penyelenggara negara dalam menyediakan berbagai layanan publik. Kewargaan aktif ini disulut dan dipicu oleh adanya ruang bereskpresi yang disediakan media tersebut. Dengan ruang publik yang telah disediakan tersebut aspirasi dan kepentingan mereka akan semakian digaungkan. Dengan demikian identitas sebagai warga negara yang memiliki hak-hak dan tanggungjawab menjadi perasaan kolektif sebagai dasar untuk mendesakkan kepentingan bersama kepada para penyedia layanan publik. Singkat kata, media massa telah ikut membantu menumbuhkembangkan identitas kolektif kewargaan aktif sehingga mampu mendorong mereka untuk selalu berpartisipasi secara aktif dalam proses pembuatan keputusan publik.

\section{Pembahasan}

\section{Media dan Demokrasi}

Lokus fungsi demokratisasi pers terletak pada sejauhmana pers telah mampu menjadi sebuah ruang publik (public sphere); sebuah ruang yang terbebas dari dominasi politik penguasa dan kepentingan ekonomi pengusaha yang memungkinkan terjadi perbincangan publik yang rasional tentang isu-isu publik yang mempengarahi kehidupan masyarakat. Ruang ini menurut Brian Mc Nair (1999;20-21) merupakan esensi lembaga komunikasi substansial masyarakat yang memungkinkan disebarluaskannya fakta dan pendapat. Di ruang yang terdiri dari stok pengetahuan publik ini dapat dibangun dasar tindakan politik kolektif masyarakat. Pada ruang ini pula, menurut Croteau (2001: 20) dimungkinkan dibentuknya sebuah ruang sosial untuk terjadinya perbincangan publik secara bebas tanpa pembatasan. Sebagai ruang publik masyarakat, maka jurnalisme hadir untuk membangun kewargaan (citizenship); untuk memenuhi hakhak warga sebab jutaan orang terberdayakan oleh arus informasi bebas. Lebih lanjut, Bill Kovach dan Tom Rosenstiel (2004:6 ) menyatakan bahwa tugas utama wartawan yakni menyediakan informasi yang dibutuhkan warga agar mereka bisa hidup merdeka dan mengatur diri mereka. Agar tugas mulia ini bisa dilakukan wartawan, Bill Kovach menyarankan sembilan hal yang mesti dipegang teguh dalam melaksanakan kegiatan jurnalistik mereka. Sembilan hal tersebut adalah:

(1) Kewajiban pertama jurnalisme adalah pada kebenaran;

(2) Loyalitas pertama jurnalisme adalah memenuhi hak mengetahui warga;

(3) Intisari jurnalisme adalah disiplin dalam verifikasi;

(4) Para wartawan harus menjaga independensi terhadap sumber berita;

(5) Jurnalisme harus berfungsi sebagai pemantau kekuasaan;

(6) Jurnalisme harus menyediakan forum publik untuk kritik maupun dukungan warga.

(7) Jurnalisme harus berupaya membuat hal-hal penting menarik dan relevan 
(8) Jurnalisme harus menjaga agar berita komprehensif dan proporsional;

(9) Para praktisinya harus diperbolehkan mengikuti nurani mereka;

Dengan nada sama, Mc Nair menyatakan demokrasi mengasumsikan adanya sebuah sistem yang terbuka yang memungkinkan warga untuk berpartisipasi. Untuk itu mereka harus diberikan akses yang memadai terhadap media dan jaringan informasi yang memungkinkan terjadinya advokasi. Demokrasi juga mengasumsikan khalayak dididik dan diberi pengetahuan yang cukup sehingga mereka dapat membuat keputusan rasional dan secara efektif menggunakan informasi yang tersebarluaskan dalam ruang publik. Lebih lanjut Mc Nair mengajukan beberapa persyaratan yang harus dipenuhi media demi memperlancara proses demokratisasi. Hal tersebut adalah ;

a. memberikan informasi kepada masyarakat tentang peristiwa yang terjadi di sekitar mereka.

b. Mendidik warga tentang arti dan nilai penting dari fakta lewat tetap menjaga objektivitas peristiwa yang diliput sebagai konsekwensi dari fungsi pendidik yang meniscayakan kemandirian profesional dari isu yang sedang diangkat.

c. Menyediakan sebuah platform bagi terlaksananya sebuah perbincangan publik tentang politik, mempermudah terbentuknya pendapat umum serta menyebarluaskan opini publik tersebut.

d. Mengaplikasikan fungsi sebagai anjing penjaga (watchdog role) dengan mempublikasikan kinerja lembaga politik dan pemerintah dengan melakukan investigasi terhadap penyimpangan yang dilakukan. Opini publik hanya akan bermakna dalam realitas politik ketika perilaku para penyelenggara kekuasaan diungkap kepada publik sehingga publik dapat menuntut pertanggungjawaban.
e. Berfungsi sebagai saluran untuk advokasi pendapat politik tertentu.

Dengan demikian, dapat disampaikan bahwa media sebagai wahana demokrasi, dengan demikian, media tak ubahnya sebuah kendaraan untuk melanggengkan kepentingan bisnis media dan sarana menangguk keuntungan belaka. Idealisme pers nasional sebagai tiang penyanggah demokrasi keempat (the fourth pillar of democracy) makanya akan sulit terwujud dalam setting media yang tunduk pada rezim pasar. Kepentingan publik pada informasi yang akurat, objektif, netral dan berimbang yang bertujuan untuk mencerdaskan dan mencerahkan warga negara (citizen) lenyap begitu saja ditelan hingar-bingar mesin-mesin raksasa kapitalis media. Demikian juga dengan fungsi kontrol sosial pers yang bermuara pada pengawasan terhadap penguasa politik dan pengusaha ekonomi akan kian melemah digerus oleh menguatnya daya dorong memenuhi ekonomi politik media kapitalis. Dengan kata lain, liberalisasi media akan mengubah karakter jurnalistik dan substansi isi media kepada kepentingan pasar. Kinerja media, menurut Croteau (2001: 20) akan semakin menjauh dari melayani dan memenuhi kepentingan publik sebab semua operasional media tidak dikelola sebagai sebagai ruang publik (public sphere); sebuah ruang sosial yang memungkinkan terjadinya perdebatan publik. Menurut Croteau (2001: 37), media massa sekarang menempatkan public atau audience sematamata sebagai consumer bukan warga negara (citizens). Tujuan utama media adalah genarate profits for owners and stockholders. Kemudian mendorong khalayak untuk enjoy themselves, view ads, and buy product. Karena itu apa yang dianggap menarik bagi publik oleh media, adalah apapun yang populer di masyarakat. Dengan demikian tujuan ideal media untuk promote active citizenship via information, education and social integration, tenggelam dengan gelombang komersialisasi dan liberalisasi. Jadinya ukuran keberhasilan media 
semata-mata adalah profit, bukan serving the public interest.

\section{Ekonomi Politik Media}

\section{Media tidak beroperasi dalam ruang hampa; tapi dikendalikan kinerjanya berdasarkan motif ekonomi politik tertentu.} Motif ekonomi media mewujud dalam dorongan untuk membuat program siaran demi meraup keuntungan sudah sedemikian menguat dan marak dalam televisi nasional. Fungsi ekonomi media lebih dikedepankan daripada fungsi mendidik dan mencerdaskan pemirsa yang merupakan tanggungjawab etis dan hukum jagat pertelevisian nasional. Kekuatan liberalisasi pasar industri media penyiaran terutama yang mulai menggejali akhir-akhir ini justru akan mengancam kualitas kebebasan pers nasional yang baru beberapa dinikmati pers nasional serta menghambat proses demokratisasi yang sedang berjalan yang mengharuskan media sebagai wahana informasi, pendidikan dan pemberdayaan masyarakat. Alih-alih sebagai sarana pendidikan dan pencerdasan masyarakat, televisi swasta nasional justru berbalik menjadi alat komersialisasi dan provokasi dengan menyebarluaskan budaya konsumtif, kekerasan, eksploitasi erotisme, serta mistik yang menumpulkan logika. Hal ini diperkuat oleh Jajak Pendapat yang dilakukan Kompas (25-08-03) bertajuk "Jajak Pendapat Kompas: Menenggak Mimpi dan Kekerasan Dari Sajian Televisi", menyimpulkan bahwa 77 persen responden membenarkan bahwa televisi saat ini cenderung mementingkan aspek komersial. Dengan dalih meningkatkan rating acara, televisi swasta berlomba-lomba untuk membuat acara 'seragam' dengan sedikit modifikasi demi menyedot perhatian untuk 'menyenangkan' pemirsa yang seringkali mengabaikan idealisme dan dampak negatif terhadap penonton. Terbukti seperti dalam survei AC Neilson periode 10-16 Agustus 2003 yang menunjukkan bahwa acara-acara hiburan yang menawarkan cerita-cerita fiktif seperti gaya hidup mewah, kesaktian serta cerita komedia menduduki peringkat atas. Fenomena yang sama juga terjadi pada tayangan berita kriminal yang mengumbar tontonan kekerasan di ruang keluarga. Ini tidak berbeda dengan acara hiburan atau talkshow yang berbau erotisme dan pornografi. Kendati telah terbiasa menyaksikan tayangan kekerasan televisi, responden menyatakan kekhawatiran mereka terhadap dampak negatif dari tayangan tersebut. Hal ini kemudian diperburuk dengan 42 persen responden menyatakan membebaskan anakanak mereka untuk menonton acara apa saja meski program siaran tidak layak dikonsumsi oleh anak mereka.

Hal tersebut menjelaskan bahwa media massa bukan hanya merupakan tempat lalu lalangnya pesan antara unsur-unsur sosial dalam suatu masyarakat, tapi juga menjadi alat penundukan dan pemaksaan konsensus oleh kelompok yang secara politik dan ekonomi dominan. Lewat pola-pola kepemilikan dan produk-produk yang disajikan, media adalah perangkat ideologis yang melanggengkan dominasi kelas pemodal terhadap publik yang diperlakukan semata-mata sebagai konsumen. Disamping itu, media juga medium untuk memciptakan opini public demi memperlancar lahirnya regulasi yang pro pasar (Agus Sudibyo:2004:1). Lewat ideologi konsumsi serta gaya hidup hedonistik, para pengelola media berlomba-lomba bersaing meraup keuntungan ekonomi dengan menyajikan tayangan-tayangan kekerasan (violence), ketakutan (horor), hasrat seksual (sex), dan ketenaran (fame) yang jauh dari nilai mendidik dan memberdayakan khalayak. Khalayak, dengan demikian, telah diposisikan sebagai objek dan konsumen yang dieksploitasi sedemikian rupa untuk memenuhi kepentingan ekonomi media. Ideologi konsumsi yang menyusup dalam tayangan media massa dapat dinyatakan sebagai berikut :

a) Berkat uang, kecantikan dapat dibeli ;

b) Keserasian keluarga tergantung dari produk yang dibeli; 
c) Dunia remaja akan penuh gairah kalau ada uang;

d) Hidup wajar berarti hidup mewah;

e) Kebahagian terbesar adalah tatkala mendapatkan hadiah;

f) Sinetron adalah pameran masyarakat konsumsi dengan latar belakang iklan;

g) Gaya hidup ideal adalah gaya hidup Amerika.

Tayangan tersebut dibuat semenarik dan seringan mungkin untuk mudah dicerna dan menghibur khalayak dari rasa penat keseharian sehingga tercipta budaya pop (popular culture). Namun, budaya pop ini dibuat dengan mengabaikan dan terkadang melecehkan nilainilai asli masyarakat setempat (local genius). Tidak heran, kalau masyarakat secara perlahan telah tercerabut dari nilai-nilai asli mereka akibat tumpulnya apresiasi mereka terhadap nilai-nilai budaya mereka sendiri (Komkat KWI:1997:23-27).

Akibat langsung dari komersialisasi media adalah melemahnya proses demokrasi serta kian tidak berdayanya masyarakat secara politik seperti yang disebut oleh Herbert J Gans $(2003 ; 15)$ sebagai political disempowerment. Hal ini karena kekuatan pasar, lanjut Croteau (2001: 21-23) memiliki beberapa kelemahan. Pertama, pasar tidak demokratis sebab pasar tidak sesuai dengan asumsi dasar demokrasi bahwa masing-masing individu memiliki hakhak yang sama. Padahal hukum pasar adalah; "the more money you have, the more influence you have in the marketplace". Kedua, pasar akan semakin melanggengkan ketimpangan sosial. Ketiga, pasar tidak bermoral sebab kepentingan utamanya adalah menjual dan memenuhi tuntutan tanpa mempedulikan adakah produk tersebut bermanfaat dan berbahaya terhadap masyarakat. Keempat, pasar tidak selamanya bisa memenuhi kepentingan sosial. Kelima, pasar tidak mampu memenuhi kepentingan demokrasi.

\section{Konsep Jurnalisme Publik/Civic}

Konsep jurnalisme civic, jurnalisme public (Jay Rosen dan Merrit) atau community journalism, citizen journalism, communitarian journalism, focus journalism, discourse journalism (Philip Meyer), conversational journalism (Anderson, Dardenne and Killenberg) biasanya digunakan secara bergantian karena ketiganya memiliki makna yang sama. Konsep ini dikembangkan dan dipopulerkan pertama kali oleh Jay Rosen di Amerika era 1990an. Rosen gelisah melihat kinerja jurnalitistik media Amerika yang sama sekali terlepas dari masyarakatnya. Seakanakan terdapat jarak antara apa yang ditampilkan wartawan dengan apa yang diinginkan warga masyarakat. Realitas yang ditampilkan media nampaknya terpisah dari realitas sosial masyarakat. Pemberitaan media bersifat elitis, hanya menampilkan segelintir warga masyarakat. Hal ini sebagai 'harga' yang harus dibayar dari praktik jurnalistik tradisional yang mengagungkan nilai objektivitas ekstrem yang membuat para wartawan harus menjaga jarak dengan realitas yang diliput demi untuk mendapatkan pemberitaan yang objektif. Berangkat dari kenyataan ini, Rosen berusaha mempertemukan kedua realitas tersebut dengan mencoba menyuguhkan pemberitaan sedemikian rupa sehingga mampu mendorong warga masyarakat untuk ikut terlibat, peduli terhadap permasalahan mereka serta berupaya menyelesaikan masalah menurut cara mereka sendiri. Konsep inilah yang kemudian disebut jurnalisem publik. Visi dari konsep ini adalah bahwa media sebagai ruang publik seharusnya menjadi wadah untuk mempersatukan semua warga masyarakat untuk saling berbicara, berdialog membahas permasalahan public dan mencari solusi terhadap masaah tersebut secara bersama-sama. Pandangan seperti dipengaruhi oleh pemikir seperti Jurgen Habermas (Konsep public sphere) dan John Dewey.

Pendapat Rosen tentang alasan munculnya konsep ini diperkuat oleh Redmond Batario, Direktur Eksekutif Center For Community Journalism and Development Filipina. Menurut Redmond, konsep ini muncul 
karena adanya beberapa kelemahan dalam praktek jurnalistik konvensional. Wartawan sering terjebak dalam pada bad news is good news syndrome. Berita cenderung bersifat dari atas ke bawah (top-down) dengan mengutip berbagai berbagai pernyataan pejabat pemerintah atau swasta. Jadi, agenda setting media lebih bersifat elitis alias dibuat oleh segelintir orang kuat. Tidak ada ruang yang cukup bagi warga masyarakat untuk menjadi nara sumber dan agenda mereka sendiri. Mereka tidak diberi kesempatan untuk menyampaikan solusi mereka sendiri, tetapi mereka selalu 'disuapi' dan dicekoki' jalan keluar oleh pihak lain yang mungkin saja belum sesuai dengan kondisi mereka. Wartawan seperti terpisah dari realitas warga masyarakat yang dikonstruksi dalam media. "Kita sering mengatakan ada masalah dalam masyarakat, tapi kita tidak menanyakan kepada mereka apakah itu memang masalah mereka," kata Red Batario. Meski demikian, kata Red Batario, konsep jurnalisme publik tidak sama sekali berpretensi mengubah konsep tradisional jurnalistik yang berupaya mengedepankan objektivitas, keberimbangan, fairness dan akurasi berita. Tapi hanya berupaya menambahkan satu aspek yakni humanizing; pelibatan warga masyarakat dalam melihat masalah. Media berkewajiban membuat masyarakat lebih proaktif dan media berfungsi sebagai katalisator.

Dengan demikian, jurnalisme publik memberi kesempatan yang luas kepada masyarakat untuk berdialog dan berdebat tentang segala hal yang mempengaruhi kehidupan mereka. Lantas, media massa memberi kesempatan kepada mereka untuk mencari solusi mereka sendiri. Berita, makanya, dalam model jurnalisme ini berasal dari bawah dan dibuat untuk mereka (bottomup). Sekedar ilustrasi, apabila media mengupas masalah korupsi, ia tidak hanya berhenti dengan menulis berita tersebut. Media harus tetap memberi kesempatan kepada masyarakat untuk melanjutkan debat tersebut hingga tercapai solusi. Ia memberikan contoh kasus lain. Ada satu kelurahan yang mempunyai masalah kekurangan pasokan air tapi ada kelurahan lain yang memiliki pengalaman menyelesaikan masalah ini. Dalam konsep jurnalisme publik, kedua cerita itu harus ditulis sekaligus untuk memberikan perspektif yang lebih bermanfaat. Media, dengan demikian, membuka debat publik bahwa ada masalah di satu kelurahan tetapi ada solusi di kelurahan yang lain. Pendek kata, jurnalisme publik memperkenalkan pendekatan baru untuk mengatur agenda pemberitaan dan bagaimana meliput pemberitaan. Caranya, memberi prioritas utama untuk diskusi publik tentang berbagai topik, serta mendorong masyarakat menemukan solusi mereka sendiri (Kompas: 02-10-2002).

Penjelasan konsep jurnalisme publik tapi dengan pengungkapan yang sedikit berbeda disampaikan Philip Meyer dalam Public Journalisme and The problem of Objectivity (31-10-2000). Menurutnya konsep ini dapat dijabarkan dalam enam dimensi seperti di bawah ini:

1. A desire to rebuild a community's sense of itself: Keinginan untuk membangun kembali perasaan sebagai warga komunitas. Peningkatan jumlah pembaca berkorelasi positif dengan komitmen pengelola media untuk menanamkan perasaan kewargaan dalam isi sajian media mereka. Semakin baik kesadaran pengelola media untuk tetap selalu menanamkan perasaan ini dalam sajian media mereka akan berpotensi meningkatkan jumlah pembaca media tersebut.

2. A longer attention span; Perhatian pemberitaan media terhadap isu tertentu hendaknya tersaji secara mendalam dengan durasi yang agak lama hingga ke akar permasalahan, tidak hanya menyentuh kepada kulit permasalahan semata. Media hendaknya memusatkan pada sebuah masalah atau isu tertentu meski kadang 
beresiko pengulangan kembali. Hal ini diharapkan nanti akan mengakibatkan terpusatnya perhatian warga masyarakat pada isu tersebut lantas membahasnya secara rasional.

3. A willingness to go deeply into explaining the systems that direct our lives: kemauan wartawan untuk lebih menjelaskan peristiwa secara mendalam dan detil.

4. More attention to the rational middle ground of issues and less attention to extremes: Perhatian lebih diberikan kepada penjelasan isu-isu dengan cara yang moderat, bukan dengan deskripsi isu yang ekstrim. Ini dimaksudkan untuk memperlancar pembuatan keputusan yang demokratis rasional. Moderasi merupaka kata kunci utama dalam demokrasi.

5. A preference for substance over tactics in covering political argument: Dalam meliput pemberitaan argument politik hendaknya dipusatkan kepada substansi masalah buka pada taktik.

6. A desire to foster deliberation: kemauan untuk menanamkan serta mendorong gairah masyarakat untuk selalu berdialog mempermasalahkan permasalah publik.

Agrawal (2006: 212) menjelaskan bahwa jurnalisme civic adalah upaya pekerja pers untuk mendorong masyarakat agar dapat terlibat dalam kehidupan publik disamping tugas rutin mereka untuk selalu memberitakan peristiwa sedang menghangat serta menjadi anjing pengawas para penyelenggara kehidupan publik. Ini menunjukkan keprihatian pekerja pers ketiadaan hubungan antara warga dengan pemerintahan bahkan antara khalayak dengan pers. Ini berkepentingan yang berupaya untuk mendorong warga terlibat dalam kegiatan proses pengambilan keputusan. Sementara itu, Jay Rosen (1999: 21) memaparkan bahwa jurnalisme publik adalah sebuah pendekatan dalam aktivitas keseharian pers yang (1) mengajak dan mendorong para wartawan untuk menempatkan masyarakat sebagai warga negara agar dapat terlibat dalam diskusi publik daripada hanya sekedar penonton atau bahkan korban dari kebijakan publik ; (2) membantu para penyelenggara layanan publik/ komunitas politik untuk dapat segera menyelesaikan masalah daripada hanya menampung keluhan dan mempelajari masalah keluhan yang disampaikan; (3) meningkatkan menggiatkan atmosfir diskusi publik daripada membiarkan nya memburuk tanpa upaya apapun; (4) membantu memperlancar kehidupan publik. Kalau ini dapat dilakukan wartawan, kepercayaan masyarakat terhadap pers akan menguat, menyambungkan kembali jalinan hubungan dengan masyarakat yang telah mulai melemah serta merevitalisasi idealisme pers.

Konsep ideal ini ternyata mendapatkan berbagai kritik dari berbagai pihak. Salah satunya adalah Paul McMasters yang secara retoris mempertanyakan adakah ini sebuah teknik, sebuah teori, atau sebuah filosofi, sebuah metode, atau tatanan baru, sebuah elaborasi tentang apa yang telah ada, atau sebuah perubahan yang radikal. Untuk memperjelas kebingungan ini Fouhy dan Schaffer mencoba mengemukakan sebuah definisi praktis : "seperangkat inisiatif jurnalistik yang berupaya menggapai, mendekati warga masyarakat untuk mendengarkan mereka dan mendorong mereka saling bebicara dan mendengarkan pendapat warga yang lain“. Disini, terkandung dua pemikiran mendasar yakni bahwa harus diakui bahwa aktivitas jurnalistik selalu tak terpisahkan dari kehidupan publik sebuah masyarakat. Selanjutnya, bahwa para wartawan memiliki tanggungjawab untuk membuat warga aktif dan peduli untuk menata dan mengelola urusan publik mereka. Ini, menurut Rosen, karena kebanyakan warga Amerika telah tidak peduli dengan urusan kehidupan publik mereka (pengambilan keputusan sosial politik). Makanya, diperlukan lembaga yang mampu menghubungkan warga dengan kehidupan publik mereka demi 
menggairahkan kehidupan demokrasi. Untuk itu, makanya, para wartawan harus rela menyingkirkan semua 'ajaran jurnalistik tradisionil'. Ini seperti penekanan yang berlebihan pada wilayah konflik kepada area harmoni/kesepakatan atau area 'abu-abu'. Juga, mengalihkan sikap bermusuhan dengan kekuasaan pemerintah kepada sikap kritik rasional yang membangun. Disamping itu, merubah sikap yang memandang khalayak sebagai penonton/pembaca pasif menjadi sikap yang melihat mereka sebagai partisipan yang aktif. Juga, adanya anggapan bahwa sikap (detached objectivity) objektif yang terpisah dari realitas akan meningkatkan kredibilitas berita wartawan. Sikap ini, harus diganti dengan asumsi bahwa wartawan hendaknya mampu memahami keragaman aspirasi warga masyarakat serta mendorong mereka untuk selalu terlibat aktif dalam menyelesaikan masalah mereka. Dengan demikian, jurnalisme civic bukan merupakan sebuah sarana pemasaran (marketing device) atau komitmen untuk meliput peristiwa dari sisi positifnya saja. Tapi, ini adalah sebuah kemitraan (patnership) antara wartawan dan warga masyarakatnya.

Namun konsepsi diatas mendapatkan kritik dari berbagai pihak. Ada yang mempertanyakan penolakan sikap objektivitas yang terlepas dari realitas. McMaster mengatakan wartawan harus terlepas dari realitas yang diliput seperti terpisahnya para fisikawan saat mendiagnosa masalah medis pasien. Hal ini, karena keterlibatan mendalam para wartawan dalam urusan masyarakat akan mengandung resiko mengorbankan kemampuan profesional wartawan. Friedland menyatakan bahwa penolakan sikap keterpisahan (detachement) tidak berarti mengambil sikap memihak dalam liputan peristiwa atau bersikap bias terhadap golongan atau posisi tertentu. Kalaupun toh ada bias, hal ini dilaksanakan dalam rangka memperlancar proses kehidupan berdemokrasi. Kritik yang lain berkenaan dengan melemahnya peran anjing penjaga (watchdog) media massa yang diamanatkan dalam (The First Amandement) Amandemen Pertama. Ini karena ketika wartawan terlibat secara penuh dalam memberikan solusi, ia akan mengasosiasikan dirinya dengan para pembuat kebijakan publik yang memimpin pelaksanaan kebijakan tersebut. Kritik selanjutnya berkenaan dengan pengutamaan kepentingan dan aspirasi warga masyarakat. Ini akan menyeret aktivitas jurnalistik ke arah riset pemasaran. Kegiatan semacam jajak pendapat ini akan menunmpulkan nilai kelayakan berita bagi kalangan wartawan sehingga isi media tak ubahnya hanya menggambarkan apa yang ingin dikonsumsi khalayak bukan mencerminkan apa yang wartawan pikirkan tentang apa yang dibutuhkan oleh khalayak. Tapi, jurnalisme publik sebenarnya lebih menaruh perhatian kepada kehidupan publik bukan dengan kegiatan jurnalistik itu sendiri. Wartawan yang berkeinginan mencerahkan wacana publik tidak akan menyajikan hal-hal absurd tapi akan menyuguhkan menu yang populer dan 'lezat' untuk disantap warga masyarakat (Paul S. Voaker: 1999: 757-758).

Agar konsep ini bisa diterapkan di lapangan, Ed Fouhy, mantan direktur eksekutif Pew Center of Civic Journalism setelah melakukan beberapa kali penelitian, mengemukakan beberapa indikator konsep jurnalisme publik. Ini bisa dijelaskan sebagai berikut:

1. Enterprise : Usaha atau kegiatan: media berusaha mengembangkan cerita berita yang didukung dengan tajuk rencana untuk memusatkan perhatian publik kepada masalah masyarakat serta mencoba menggerakkan mereka untuk menyelesaikan persmasalahan tersebut. Ini karena jurnalisme ini bermaksud untuk menggairahkan kehidupan publik; wartwan memiliki tanggungjawab terhadap kesehatan serta keberlangsungan kehidupan publik masyarakat dengan cara membuat mereka aktif terlibat dalam menyelesaikan masalah mereka. Singkat kata, dalam benak wartawan 
harus tertanam pandangan tentang bagaimana meningkatkan kesehatan kehidupan publik bukan bagaimana membuat berita yang bagus. Juga, bagaimana memperkuat komitmen untuk membantu masyarakat menyelesaikan masalah mereka.

2. Information for decision making : ketersediaan informasi yang cukup untuk membuat kebijakan : media menyuguhkan beberapa pilihan penyelesaian masalah beserta resiko yang terkandung dalam setiap pilihan. Ini yang disebut sebagai public judgement; kemampuan menilai publik. Peran utama wartawan adalah untuk memberdayakan warga masyarakat untuk bukan hanya berkomunikasi di arena publik tapi juga bekerja mencari penyelesaian masalah tanpa harus dipengaruhi kepentingan para pembuat kebijakan. Wartawan bukan hanya mendengarkan dan mengakomodir komentar publik tapi juga memaparkan hasil riset mandiri tentang alternatif pandangan publik yang diharapkan mampu mencerdaskan ketrampilan penilaian publik mereka. Hal ini juga meliputi usaha wartawan untuk memantau tanggapan pembuat kebijakan tentang beragam alternatif solusi tersebut. Dengan cara liputan seperti ini, diharapkan akan menanamkan perasaan sebagai warga masyarakat. Ini juga mencakup dimensi kewajiban wartawan untuk mengidentifikasi nilainilai utama yang akan dijadikan patokan dalam diskusi publik dengan warga masyarakat.

3. Facilitation of discourse: kemudahan berwacana: media menyelenggarakan pertemuan warga (town hall meeting) untuk menemukan isu-isu utama yang berkembang dalam masyarakat dan menindaklanjutinya dengan pemberitaan tentang isu-isu tersebut beserta beberapa alternatif penyelesaian. Hal penting yang menentukan kesuksesan diskusi publik adalah pengakuan terhadap fakta bahwa warga merasa memiliki kesempatan untuk mendiskusikan masalah mereka di forum publik bukan hanya sekedar membaca isu-isu tersebut dalam sajian pemberitaan media. Makanya, agar diskusi publik ini tetap terjaga keajegannya, media biasanya menyelenggarakan pertemuan publik untuk membahas isuisu mendesak yang perlu ditanggapi bersama.

4. Attention to Citizens' Cencerns: perhatian terhadap aspirasi warga masyarakat; media mengadakan jajak pendapat untuk menentukan masalah yang paling mendesak lantas mendorong para pemimpin untuk memusatkan kebijkan mereka pada isuisu ini. Ini berarti menolak agenda yang telah ditentukan oleh otoritas politik dan ekonomi serta mengganti agenda warga.

Dengan demikian dapat disimpulkan bahwa jurnalisme publik merupakan model jurnalisme yang menyertakan masyarakat sebagai bagian dari informasi. Bahkan paradigmanya menempatkan masyarakat sebagai subjek, melalui usaha jurnalistik yang meningkatkan kualitas hidup masyarakat. Menurut Erol Jonathan (2002:3-4) model jurnalisme ini bisa mengandung makna sebagai berikut:

- Jurnalisme yang memfungsikan diri sebagai penyulut semangat golongan masyarakat yang lemah dan tak berdaya serta terpinggirikan.

- Jurnalisme yang membantu kreativitas jurnalisme untuk memotivasi masyarakat berpikir dan berbuat ketika mengkonsumsi informasi. Tujuannya bukan sekedar untuk mengkonsumsi informasi. Tapi menyadarkan masyarakat untuk mewujudkan rasa 
tanggung jawab mereka terhadap lingkungan.

- Jurnalisme yang memberdayakan masyarakat dalam posisi netral, yang berisi sekedar informasi atau cara mewujudkan tanggung jawab dan imaginasi solusi terhadap berbagai masalah masyarakat.

- Jurnalisme yang menawarkan alternatif model penyelenggaraan pemerintahan. Yaitu pemerintahan yang terbuka, transparan dan melibatkan masyarakat dalam setiap proses penyusunan kebijakannya.

- Jurnalisme yang mendefinisikan kembali mazhab keberimbangan dalam pengertian sesungguhnya. Berimbang karena melibatkan masyarakat sebagai pelaku informasi dan memberi peluang mereka sebagai pengawas.

- Jurnalisme yang menggeser konsep "watchdog" menjadi "guide dog". Yakni Jurnalisme yang terkontrol karena pemberitaannya tidak hanya menyajikan berita dan informasi tapi juga menolong masyarakat melaksanakan kewajibannya sebagai warga masyarakat. Ini berarti jurnalisme yang tidak hanya mengetengahkan masalah masyarakat tetapi juga menantang masyarakat terlibat aktif, peduli dan ikut serta menyelesaikan masalah. Dengan kata lain, jurnalisme yang menjadikan masyarakat sebagai partisipan, bukan melulu sebagai penonton.

Meski dengan penamaan yang berbeda, jurnalisme publik merupakan jurnalisme pluralistik yang merupakan interaksi secara segitiga antara pemberitaan, komunikasi dan masyarakat (Shelton Gunaratne : 3-04-05). Ini dapat dijelaskan sebagai berikut:

a. Nilai kelayakan berita konvensional seperti kedekatan, ketokohan, konflik dan keanehan hendaknya ditinjau kembali sebab tidak sesuai dengan perkembangan jaman. Sekarang, berita hendaknya merupakan sebuah narasi yang koheren yang memberikan nilai tambah kepada khalayak. Berita yang selama ini ditransmisikan secara linier sebagai komoditas harus dikaji ulang. Ini karena berita harus memberikan kontribusi positif terhadap kesuksesan kehidupan publik dengan mencoba mengembangkan perspektif multikulutural dan kesetaraan gender.

b. Aktivitas jurnalistik harus lebih dipandang sebagai kegiatan komunikasi antar insani yang mengharuskan wartawan untuk mendengarkan lebih dekat kepada aspirasi khalayak dan berupaya mempermudah proses dialog antara sesama mereka. Dengan demikian, warga masyarakat mampu berbicara antara mereka sendiri tentang masalah untuk menemukan solusi masalah yang sedang mereka hadapi. Ini hendaknya juga mendorong munculnya komunikasi yang partisipatoris untuk menciptakan rasa saling pengertian di antara warga masyarakat.

c. Wartawan hendaknya menjadi seorang partisipan yang terbuka dalam masyarakat; harus menjadi pendorong dialog yang terkait dengan realitas masyarakat sehingga mereka merasa berdaya untuk mengambil keputusan mereka sendiri.

\section{Jurnalisme Warga (citizen journalism)}

Prinsip dasar dunia maya memang membuka ruang budaya yang demikian, sedikit demi sedikit user mulai mengerti dengan ciri tersebut. Pengertian ini menggiring kepada pemahaman yang lebih mutakhir, sehingga dapat lebih memegang kendali atas teknologi. Bukan sebaliknya, manusia yang justru dikendalikan oleh teknologi. Dalam tren kondisi yang demikian lahirlah beragam ruangruang baru di dunia maya yang makin progresif. Salah satunya adalah weblog atau yang kini jamak disebut blog. Blog bermula dari catatan harian atau jurnal seseorang yang 
dipublikasikan di internet. Selain catatan yang sifatnya personal dan selalu di-up-date tersebut, blog juga menyajikan link atau daftar alamat koneksi ke situsweb atau blog lainnya. Ciri khas lainnya adalah blog memungkinkan setiap pengunjungnya meninggalkan komentar terhadap apa yang tampil di situ. Pengunjung lainnya dapat melihat komentar tersebut dan dapat memberikan komentar lanjutan, demikian juga dengan pemilik blognya, begitu seterusnya.

Inilah cikal bakal situsweb citizen journalism yang kini mulai menjamur sebagai bentuk alternatif dari praktik jurnalistik. Dunia web adalah dunia yang berbasis pada link. Setiap orang atau entitas dapat saling terkait dengan orang/entitas lainnya. Prinsip ini mengakomodasi kebutuhan dasar manusia untuk berkomunikasi, atau meminjam istilah salah seorang perintis gerakan citizen journalism di AS, Dan Gillmor: saling bercakap-cakap (Gillmor dalam Rosen, 2004). Setiap orang ingin mengekspresikan diri, pikiran, keresahan, dan harapannya. Setiap orang juga ingin mendengarkan atau membaca dan memahami pikiran, keresahan, serta harapan orang lain. Selain itu, hasrat membantu orang lain atau paling tidak memberikan komentar atas pikiran orang lain juga amat naluriah. Hal-hal itulah yang kemudian benarbenar mendapatkan ruangnya di dunia web, blog, dan termasuk juga kini citizen journalism. Gerakan jurnalisme baru ini mengemuka pada awal 1990-an di AS. Belum ada data yang pasti siapa yang memulainya karena masih ditemukan klaim-klaim yang sifatnya pribadi tanpa uji silang yang komprehensif. Meski begitu, era kemunculannya memang pada rentang waktu tersebut. Bentuk dan sifatnya masih beragam tergantung kepentingan setiap pembuatnya dan semuanya berbasis pada aplikasi blog. Satu hal yang pasti adalah semangat jurnalisme partisipatoris sudah muncul dan menonjol. Karena memang sejatinya inilah ciri pokok citizen journalism. Yakni, kegiatan jurnalistik yang dilakukan bukan oleh jurnalis profesional, tetapi oleh masyarakat umum dan dipublikasikan secara online serta dapat saling diberi komentar oleh pengguna lainnya.

Konsep dasar dalam citizen journalism yaitu memposisikan audiens sebagai produsen berita juga, bukan hanya konsumen pasif seperti selama ini berjalan dalam logika kerja jurnalisme tradisional berbasis media massa. Dengan kata lain, posisi antara jurnalis sebagai pencari dan penulis berita, narasumber sebagai muasal berita, dan audiens sebagai konsumen berita sudah lebur begitu cair. Antara produsen dan konsumen berita tidak bisa lagi diidentifikasi secara rigid karena setiap orang dapat memerankan keduanya (Gillmor, 2004: xii-xv). Intinya, dalam citizen journalism yang diutamakan adalah interaksi dan interkoneksitas.

Di samping itu, prinsip dasar citizen journalism yang lain adalah bahwa berita adalah merupakan produk konstruksi bersama antara wartawan dengan pembaca. Jika sebelumnya berita sebatas dimaknai sebagai peristiwa yang dilaporkan melalui media massa (Simbolon, 2006: 87), kini berita menemukan makna tersendiri lewat citizen journalism. Berita bukan lagi sesuatu yang elitis dan hanya punya "satu sisi muka" karena tidak muncul dari sekelompok orang tertentu yang berlabel jurnalis profesional saja. Setiap orang yang mempunyai cerita kehidupan dan berdampak sosial dapat menuliskannya di situsweb yang berprinsip citizen journalism. Berita di media massa memang bukan realitas sosial itu sendiri. Melainkan, realitas media yang juga sudah melalui proses konstruksi atas realitas sosial. Akan tetapi, proses konstruksinya selama ini hanya berkutat di jajaran redaksi media tersebut. Atau dengan kata lain, masih elitis. Media massalah yang menentukan apa yang harus diliput dan apa yang luput dari pelaporan peristiwa. Media pula lah yang memastikan nilai berita mana yang lebih penting untuk pembacanya. Media massa menentukan berbagai faktor untuk menentukan peristiwa 
apa yang akan mereka liput (Anderson dan Itule, 1984: 17).

Pola demikian yang kemudian didekonstruksi oleh prinsip citizen journalism dalam dunia cyber. Setiap orang kembali kepada definisi asali dari berita itu sendiri, yakni segala sesuatu yang diinginkan dan diperlukan untuk diketahui oleh orang lain (Newsom dan Wollert, 1985: 11). Dengan melaporkan berita, media tidak hanya berbagi informasi kepada khalayak untuk kemudian menggerakkan masyarakat dalam perikehidupan demokratis, tetapi juga menjadi ruang interaksi antar individu maupun ruang dialog yang konstruktif. Berita mewujud sebagai sebuah laporan dari warga yang bisa jadi bernuansa subyektif, tetapi mampu menjadi sarana dialog untuk menemukan tesis dan sisntesis kehidupan bersama.

\section{Penutup}

Kinerja pers nasional diukur sejauhmana produk-produk jurnalistiknya dapat meningkatkan partisipasi warga. Ini mengingat fungsi utama pers adalah layanan public/ public service. Kepentingan publik dapat dipernuhi dengan memenuhi hak rakyat untuk tahu (the people's right to know) yakni memberitakan peristiwa yang menjadi kepentingan semua warga, mencakup kepentingan seluruh warga masyarakat. Untuk itu, jurnalisme publik merupakan keniscayaan sejarah kalau media nasional ingin mensukses proses demokrasi bangsa. Dengan demikian, partisipasi warga untuk terlibat dalam kegiatan proses pengambilan keputusan publik akan kian marak. Pers di sini menjadikan dirinya sebagai forum diskusi publik berkaitan dengan isu-isu publik. Pers benar-benar menjadi ruang publik (public sphere); sebuah ruang yang memang didedikasikan untuk kepentingan publik.

Kemunculan jurnalisme warga akan kian menggiatkan komunikasi warga dengan pemerintah serta juga dengan pers. Keberadaan citizen journalism tidak serta merta mengeliminasi keberlanjutan hidup media massa konvensional. Terlebih lagi di Indonesia yang mayoritas warganya belum mampu mengakses internet secara kontinyu karena kemiskinan struktural yang tercipta sebagai turunan dari perikehidupan yang korup dan timpang selama negeri ini merdeka. Saat ini, elitisme pengetahuan sudah tidak ada lagi. Informasi dan pengetahuan tidak hanya berada di tangan para pekerja media. Bisa jadi khalayak media tersebut justru lebih dulu tahu karena kecepatan akses informasi melalui internet. Hal ini tidak menjadi soal. Sebabnya, saat ini pertanyaan utama dalam ranah jurnalistik bukan lagi siapa yang lebih dulu dan lebih cepat tahu. Melainkan, bagaimana informasi dan pengetahuan yang mereka miliki tersebut dapat memberi manfaat bagi kehidupan bersama. Nah, agar dapat memberi manfaat, maka informasi tidak lagi dipasung sendirian.Justru interaksi dan proses dialog lah yang memungkinkan suatu peradaban bertambah maju. Dengan begitu, para jurnalis profesional tidak pelu khawatir dengan geliat citizen journalism di dunia maya. Para jurnalis tersebut dapat memanfaatkannya sebagai ruang alternatif dalam mengolah informasi dan mengkonstruksi realitas sosial menjadi realitas media. Sementara, keberadaan citizen journalism juga tetap dapat memberikan andil positif bagi ruang hidup yang demokratis. Di samping melatih setiap orang untuk lebih peka terhadap lingkungan sekitarnya, citizen journalism juga bisa menjadi sarana alternatif melihat konstruk realitas sosial yang luput dari perhatian media massa. Inilah konvergensi yang penulis maksudkan. Dengan begitu, kecenderungan negatif laju media massa dalam kancah kapitalisme global dapat ditekan. Kecenderungan itu di antaranya adalah arogansi dalam melihat, memilih, dan memaknai setiap realitas sosial. Arogansi ini memang mendapat ruang yang luas selama ini karena logika jurnalistik yang berjalan bersifat elitis. Posisi sebagai gatekeeper justru menunjukkan arogansi tersebut ketimbang mendukung proses demokratisasi. Pekerjaan rumah yang terdekat saat ini bagi pekerja media profesional adalah menajamkan pemahaman terhadap situasi sosial yang makin mutakhir. 


\section{Daftar Pustaka}

Agrawal, Bala, Vir, 2006, Essentials of Practical Journalism, Concept Publishing Company, New Delhi, India

Anderson, Douglas A; Itule, Bruce D. 1984. Contemporary News Reporting. New York: Random House.

Croteau, David \& Hoynes, William, (2001), The Business Of Media: Corporate Media and The Public Interest, Pine Forge Press, California, USA.

Dirgahayu, Dida, Citizen Journalism Sebagai Ruang Publik (Studi Literatur Tentang Untuk Menempatkan Citizen Journalism Berdasarkan Teori Jurnalistik dan Mainstream Media, dalam Jurnal Observasi, Kajian Komunikasi dan Informatika, Mengamati Fenomena Citizen Journalism, 2007, Simbiosa Rekatama Media, Bandung,

Gans, Robert J., 2003, Democracy and The News, Oxford University Press, New York, USA

Gunaratne, Shelton dalam Old Wine in a New Bottle: Public journalism movement in the United States and the erstwhile NWICO debate $\mathrm{di}$ http://www.mnstate.edu/gunarat/index/htm 1 (3-04-05).

Gillmor, Dan. 2004. We The Media: Grassroot Journalism by The People, for The People. California: O'Reilly.

Glasser, Theodore L, 1999, The Idea of Public Journalism, The Guilford Press, New York, USA

Glaser, Mark. 2006. "Your Guide to Citizen Journalism", diunduh dari http://www.pbs.org/mediashift/2006/09/di gging_deeperyour_guide_to_ci.html, diakses pada 14 Mei 2008.

Ishwara, Luwi. 2005. Catatan-catatan Jurnalisme Dasar. Jakarta: Penerbit Buku Kompas.

Jonathan, Errol, (2002), Resistensi Masyarakat Dalam Menerima Informasi Global, Makalah disampaikan pada; "Seminar Nasional: Dampak Perkembangan Komunikasi Global Di Tengah Masyarakat". Di Univeritas 17 Agustus Surabaya, 21 Juni 2002.

Kim, Minha., 2012, News Objectivity and Political Conversation: An Experimental Study of Mad Cow Disease and Candlelight Protest, Development and Society, Volume 41 | Number 1 | June 2012.

Kovach, Bill \& Rosenstiel, Tom., (2003), Sembilan Elemen Jurnalisme, Pantau, Jakarta.

McQuail, Dennis, (1992), Media Performace: Mass Communication and The Public Interest, Sage Publication, London

McChesney, Robert W, 2000, Rich Media, Poor Democracy: Communication in Dubious Politics, The New Press, New York, Amerika Serikat. 1997, Corporate

Media and The Threat To Democracy, Seven Stories Press, New York, diterjemahkan oleh Andi Ahdian, 1998, Konglomerasi Media Massa Ancaman Terhadap Demokrasi, Aliansi JUrnalis Independen, Jakarta

Meyer, Philip, Public Journalism and The Problem of Objectivity dalam http://www.unc.edu/-pmeyer/ire95pj.htm (31-10-00). 
Newsom, Doug; Wollert, James A. 1985.

Media Writing, News for The Mass

Media.California: Wadsworth.

Rosen, Jay. 2004. "A Conversation Between

Dan Gillmor and Jay Rosen", diunduh dari

http://www.oreillynet.com/pub/a/network/200

4/09/14/gillmor.html?CMP=ILCFV75114

46129\&ATT $=1462$, diakses pada $14 \mathrm{Mei}$

2007

Rosen, Jay., 1999, The Action of the Idea:

Public Journalism in Built Form, dalam

Glasser, Theodore L, 1999, The Idea of

Public Journalism, The Guilford Press,

New York, USA

Simbolon, Parakitri T. 2006. Vademekum

Wartawan. Jakarta: Kepustakaan Populer

Gramedia.

Sudibyo, Agus, (2004), Ekonomi Politik Media Penyiaran, LKIS, Yogyakarta.

Santana, Setiawan, Jurnalisme yang Memihak

Publik, Jurnal Observasi, Kajian

Komunikasi dan Informatika, Mengamati

Fenomena Citizen Journalism, 2007,

Simbiosa Rekatama Media, Bandung,

Supriadi, Dandy, Online Citizen Journalism; Memantapkan POsisi Warga Dalam Demokrasi, dalam Jurnal Observasi, Kajian Komunikasi dan Informatika, Mengamati Fenomena Citizen Journalism, 2007, Simbiosa Rekatama Media, Bandung,

Suryana, Nana, Citizen Journalism:

Partisipasi dan Masyarakat Informasi, dalam Jurnal Observasi, Kajian Komunikasi dan Informatika, Mengamati Fenomena Citizen Journalism, 2007, Simbiosa Rekatama Media, Bandung,

Voakes, Paul S., (1999), Civic Duties:

Newspaper Journalits' View on Public Journalism, dalam Jurnal Journalism \& Mass Communication Quarterly, Winter 1999/ 76/4.

Yudhapramesti, Pandan, Citizen Journalism Sebagai Media Pemberdaya Warga dalam Jurnal Observasi, Kajian Komunikasi dan Informatika, Mengamati Fenomena Citizen Journalism, 2007, Simbiosa Rekatama Media, Bandung, 